\title{
Učestalost reduktivnih i drugih nepoželjnih mirisa vina u kontroli kakvoće
}

\begin{abstract}
Sažetak
Miris vina je kompleksna i kreativna referenca kakvoće i vrlo važan čimbenik u izboru vina. Nepoželjni mirisi stoga nisu prihvatljivi, a neki mogu biti i štetni za zdravlje. Posljednjih dvadesetak godina posebice se bilježi porast kompleksnih neugodnih sumpornih mirisa. Cilj ovog rada bio je analizirati učestalost pojave nepoželjnih mirisa u hrvatskim vinima prije stavljanja na tržište. U analizi su korišteni rezultati senzornih ispitivanja vina za razdoblje 2008.-2019., za oksidaciju, octikavost, etil acetat, sumporovodik i merkaptanske mirise, kao glavne probleme mirisa. Uočen je trend pada udjela loših uzoraka u odnosu na čitavo promatrano razdoblje. Dodatna analiza provedena je za sumporne nepoželjne mirise, za razdoblje 2014.-2019., pri čemu je utvrđen porast problema reduktivnih mirisa općenito, a posebno izražen porast mirisa merkaptanskih spojeva. Obzirom na brojnost $i$ složenost čimbenika kakvoće, ovi rezultati upućuju na potrebu kontinuirane kontrole proizvodnje i traženja načina za sprečavanje nastanka nepoželjnih mirisa vina.
\end{abstract}

Ključne riječi: nepoželjni mirisi vina, sumporovodik, merkaptanski spojevi, senzorna analiza

\section{Uvod}

Povijest prerade grožđa i uživanja vina staru preko 8000 godina (Mc Govern i sur., 2017) sigurno od samih početaka prati i potreba razumijevanja dobre i loše kakvoće.

Miris je jako važno senzorno svojstvo za potrošače (Rimkute i sur., 2015). Važnost mirisa očituje se i kroz činjenicu da 75\% emocija generirano mirisom (Bell i Bell, 2007). Prema Vlahosu (2007) naš njuh je najjače osjetilo u odnosu na pamćenje; vjerojatnost da ćemo se sjetiti nečega što mirišemo nego nečega što vidimo, čujemo ili dodirnemo je 100 puta veća. Doživljaj lošeg mirisa utječe na novu odluku o izboru vina i stoga je razumljiva konstantna zainteresiranost za ovu temu (Mueller i sur., 2010).

Najčešći razlog loše kakvoće vina su nepoželjni mirisi i obzirom na uzroke nastanka i učestalost pojave, mogu biti grupirani na različite načine. Najvažniji i najčešći su problemi reduktivnih mirisa sumporovodika i merkaptana, te oksidacija, octikavost i etil acetat. Svi navedeni problemi su stari koliko i vino i do danas nisu riješeni, a čimbenici pojave mogu biti vezani uz grožđe (Steel i sur., 2013), metabolizam kvasaca i bakterija tijekom fermentacije (Ferreira, 2011), te kemijske reakcije tijekom stabilizacije i dozrijevanja vina (Huddelson, 2011). lako je najčešći razlog loše kakvoće vina i danas oksidacija, oksidiranih vina značajno je manje. S promjenama navika i usvajanjem novih tehnologija, oksidiranih vina kakve smo imali prije tri desetljeća gotovo više nema. Poznato je da je oksidacija prvenstveno vezana uz acetaldehid u vinu, vodeći spoj karbonilne grupe potencijalno toksičnih spojeva. Acetaldehid spada u skupinu 2B kancerogenih spojeva, dok je kao spoj koji se unosi konzumacijom alkoholnih pića klasificiran u kancerogenu skupinu 1 (IARC, 1999.). lako postoje brojni podaci o sadržaju ovih spojeva u vinu, s naglaskom na acetaldehid (Jackowetz i De Orduña, 2013), uobičajene količine u vinu su neopasne, te stoga nema propisanih ograničenja sadržaja u vinu, kao što nije moguće jednostavno povezati određenu koncentraciju spoja sa senzornom prepoznatljivošću (Villamor i Ross, 2013).

Nasuprot oksidaciji i acetaldehidu, hlapljiva kiselost kao parametar kakvoće, ali negativne, izdvojen je u vinskom zakonodavstvu s propisanim dopuštenim granicama u većini zemalja, iako spojevi koji participiraju u hlapljivoj kiselosti nisu prijetnja zdravlju poput acetaldehida.

Dr.sc.IvanaAlpeza,IvnaLinke, dipl.ing.agr., Hrvatskaagencijaza poljoprivreduihranu(CroatianAgencyforAgricultureandFood) Jandrićeva 42, 10000 Zagreb, Hrvatska

Autor za korespondenciju: ivana.alpeza@hapih.hr 
Međutim, iako senzorna percepcija loše kakvoće vezane uz hlapljivu kiselost jako varira i značajno ovisi o sadržaju etil acetata (Cliff i Pickering, 2007, Zoecklein, 2012), octikavost je ozbiljan mikrobiološki problem i narušava osnovna svojstva vina.

Između navedenih problema, sumporni spojevi nepoželjnog mirisa zahtijevaju posebnu pozornost. Unatoč svim tehnološkim postignućima, riječ je o problemu za koji možemo kazati kako je globalan ozbiljan problem i za koji se, za razliku od oksidacije i octikavosti/etil acetata, bilježi porast pozornosti u odnosu na prije nekoliko desetljeća, prvenstveno zbog sve češće pojave kompleksnijih oblika nepoželjnih mirisa (Muller and Rauhut, 2018). Prema Goode i Harrop (2008) podaci analize trogodišnjeg uzastopnog ocjenjivanja International Wine Challenge (I.W.C.), s više od 10000 vina godišnje, pokazali su kontinutet problema reduktivnih mirisa vina u boci na svjetskoj razini. Prema autorima udio loših vina bio je od 7,1\% 2006. do 5,9\% 2008. godine. Udjel uzoraka s reduktivnim mirisima bio je između 29,2 i $26,5 \%$, pri čemu ukupan pad loših vina nije pratio i pad problema reduktivnih mirisa. Problem reduktivnih mirisa je evidentiran i u vinima s navojnim čepom, između 2,2 i 2,6\%. Problem sumporovodika kao najveće mane mladih vina star je koliko i primjena sumpora (Rankine, 1963), tj. sumpornih pripravaka u vinogradarstvu. Tako Biankini (1884) opisuje „tek po smrdljivim jajim“ kao noviju manu vina koja je došla,,sa liekom proti nedaći“, tada zvane maća ili lug, a“sumporni cviet" (prah) korišten je više puta, kako u vinogradu tako i u higijeni bačava. No, za razliku od jednostavne mane mirisa sumporovodika koji ni tada nije utjecao na cijenu vina (Biankini, 1884), problem je danas puno kompleksniji. Sumporni spojevi imaju različita senzorna svojstva ovisno o kemijskoj strukturi (tablica 1.) i predstavljaju najveću nepoznanicu u kemiji vina danas.

Tablica 1. Negativni sumporni spojevi i pripadajući mirisi u vinu

Table 1. S-compounds with negative smell and coresponding description

\begin{tabular}{|c|c|c|c|}
\hline Kemijski spoj/Compound & Senzoran opis/Sensory description & $\begin{array}{l}\text { Prag prepoznavanja/ } \\
\text { Detection thresholds }(\mu \mathrm{g} / \mathrm{L}) /\end{array}$ & $\begin{array}{c}\text { Raspon / } \\
\text { Range }(\mu \mathrm{g} / \mathrm{L})\end{array}$ \\
\hline $\begin{array}{l}\text { Sumporovodik/Hydrogen sulfide } \\
\text { metil merkaptan/ }\end{array}$ & $\begin{array}{l}\text { trula jaja, reducirajući okus u ustima, } \\
\text { miris kanalizacije }\end{array}$ & $0,001-150$ & $0-370$ \\
\hline Methylmercaptan & kuhani kupus, reduktivan okus & 0,3 & $0-16$ \\
\hline etil merkaptan/Ethyl mercaptan & miris luka, spaljena guma, trulež & 43831 & $0-50$ \\
\hline dimetil sulfid/Dimethyl sulfide & kupus/zelje, šparoge, kukuruz, melasa & $10-160$ & $0-910$ \\
\hline ugljik disulfid/ Carbon disulfyde & kupus/zelje, guma & $>38$ & $0-18$ \\
\hline $\begin{array}{l}\text { dimetil trisulfid/ } \\
\text { Dimethyltrisulfide }\end{array}$ & $\begin{array}{l}\text { kupus/zelje, različite sorte luka, kuhano } \\
\text { povrće }\end{array}$ & 0,1 & $0-111$ \\
\hline dietil sulfid/Diethyl sulfide & češnjak & 0,93-18 & $0-10$ \\
\hline $\begin{array}{l}\text { dimetil disulfid/Dimethyl } \\
\text { disulfide }\end{array}$ & kuhani češnjak, šparoga, luk & $20-45$ & $0-160$ \\
\hline dietil sulfid/Diethyl sulfide & češnjak, luk, spaljena guma & $4,3-40$ & $0-160$ \\
\hline $\begin{array}{l}\text { 2-merkaptoetanol/ } \\
\text { 2-Mercaptoethanol }\end{array}$ & miris staje, peradi, seoskog dvorišta & 130 & $0-400$ \\
\hline Metiltioacetat/Methylthioacetate & sumporasti miris, trulo povrće & 300 & $0-115$ \\
\hline Etiltioaacetat/Ethylthioacetate & sumporastimiris & 40 & $0-180$ \\
\hline $\begin{array}{l}\text { 2-metiltio-1-etanol,2 metil } \\
\text { merkaptoetanol/ } \\
\text { 2-(Methylthio)-1-ethanol }\end{array}$ & karfiol, mahune (francuskigrah) & 250 & $0-139$ \\
\hline $\begin{array}{l}\text { 2-metiltio-1-propanol/ } \\
\text { 2-(Methylthio)-1-propanol }\end{array}$ & karfiol, kuhani kupus & 1200 & $0-5655$ \\
\hline $\begin{array}{l}\text { 2-metiltio-1-butanol/ } \\
\text { 2-(Methylthio)-1-butanol }\end{array}$ & luk, češnjak, zemlja & 100 & $0-180$ \\
\hline Benzotiazol/Benzothiazol & guma & $50-350$ & $0-30$ \\
\hline $\begin{array}{l}\text { 5-2hidroksietil-metiltiazol/ } \\
\text { 5-(2-Hydroxethyl)-4-ethylthiazole }\end{array}$ & miris na zeleno, biljni & $100-1000$ & $5-50$ \\
\hline
\end{tabular}

Izvor/Source: Fracasetti i Vigentini (2017) 
Broj poznatih spojeva koji su uzročnici ove mane danas je značajno veći nego prije dvadestak godina (Thoukis i Stern 1962), no i dalje ovaj problem nije pod kontrolom (Fracassetti and Vigentini, 2017). Razlozi tome su raznovrsno podrijetlo ovih spojeva, njihova reaktivnost $\mathrm{i}$ niski pragovi prepoznatljivosti. Kemijska reaktivnost sumpornih spojeva očituje se u brojnim oblicima reakcija u kojima sudjeluju stvarajući u početku oblike u vrlo niskim koncentracijama, ispod praga prepoznatljivosti. Tijekom reduktivnih uvjeta starenja u bačvi ili boci nastaju novi različiti kemijski oblici u koncentracijama iznad pragova prepoznatljivosti (Franco-Luesma i Ferreira, 2014, Kinzurik i sur., 2016)). Ova kemijska reaktivnost spojeva koji sadrže sumpor predstavlja stoga izazov; kako prepoznati uvjete pod kojima se sintetiziraju prije nego su primijećeni. Znanost i struka još uvijek nije pronašla učinkovite metode za uklanjanje ovih spojeva iz vina; najbolja strategija je zaštititi vino od njihove sinteze.

Hrvatska vinska scena sve je brojnija proizvođačima i vinima. Potrošači znaju sve više, dostupan im je veliki broj različitih oblika informiranja i žele proizvod koji će biti prepoznatljiv i autentičan. Mirisi koji nisu tipični za vino ili određenu sortu, pogotovo mirisi negativnog predznaka sigurno nisu poželjni. Praćenjem problema kakvoće kroz različite oblike suradnje i komunikacije na znanstvenoj stručnoj razini prepoznat je problem sumpornih spojeva, s naglaskom na sve kompleksnije nepoželjne mirise kojih prije dvadesetak godina nije bilo. Dostupnih podataka u literaturi nema, ni o problemu u vinima u proizvodnji, niti na tržištu. Stoga je cilj ovog rada bio dobiti relevantne podatke o učestalosti najvažnijih mirisnih mana s naglaskom na reduktivne mirise sumporovodika i merkaptana u hrvatskim vinima prije stavljanja na tržište.

\section{Materijali i metode}

\section{Uzorci}

Korišteni podaci u ovom istraživanju temeljeni su na analizi rezultata senzornih ispitivanja kakvoće hrvatskih vina prije stavljanja na tržište. Analizirano je razdoblje od 2008. do 2019. za opće pokazatelje kakvoće, a razdoblje između 2015. i 2019. godine u odnosu na razloge loše kakvoće, s naglaskom na mane reduktivnih mirisa sumporovodika i merkaptana. Podaci za ciljanu analizu su dobiveni filtriranjem baze podataka koja sadrži podatke senzornih ispitivanja svih vrsta uzoraka za razdoblje 2008.-2019. U konačnu analizu su uključeni isključivo pouzdani rezultati senzornih ispitivanja uzoraka hrvatskih vina za tržište. Senzorna ispitivanja

Rezultati senzornih ispitivanja temeljeni su na primjeni dvije metode; brojčanoj metodi „100 bodova“ i deskriptivnoj metodi „Da/Ne“. Konačan rezultat u brojčanoj metodi je medijan pet ocjenjivača, a u deskriptivnoj metodi konačan rezultat ovisi o broju odgovora da ili ne i uz pet ocjenjivača rezultat je pozitivan uz minimalno tri odgovora da. Negativan rezultat kod obe metode mora biti obrazložen, a uzorak može biti odbačen na bilo kojem od senzornih svojstava; bistroće, boje, mirisa ili okusa. Uz negativan odgovor ocjenjivač obvezno navodi stručno utemeljen i objašnjiv razlog; bolest, manu ili kombinaciju razloga u odnosu na ispitivane parametre i prezentirane informacije. Bez obzira na konačan rezultat, rezultat mora biti i pouzdan, što je dodatan interni alat osiguranja kakvoće ispitivanja. Pouzdan negativan rezultat je svaki rezultat kod kojeg minimalno $60 \%$ ocjenjivača navodi jednake stručne atribute kao opisne deskriptore loše kakvoće.

Navedene metode propisane su nacionalnim provedbenim propisom $\left(\mathrm{NN}^{2}\right)$, a tehnički uvjeti provedbe bili su u skladu s ISO/DIS 8589 normom. Postupci ispitivanja akreditirani su prema normi HRN EN ISO/IEC 17025. Ocjenjivači su visokoobrazovani vinogradarsko vinarski stručnjaci s minimalno pet godina iskustva u struci i verificiranim sposobnostima i znanjem o senzorici vina na profesionalnoj razini. 


\section{Obrada podataka}

Obrada podataka provedena je korištenjem programa Microsoft Excel, 2017 (Microsoft Office, Redmond, WA, USA).

\section{Rezultati i rasprava}

Podaci o udjelu senzorno loših uzoraka vina u odnosu na ukupan broj senzornih ispitivanja prikazani su u tablici 1. Udjel loših uzoraka u promatranom razdoblju bio je između 9,5 i 15,3\%, što je značajan udjel u odnosu na broj uzoraka u ispitivanju.

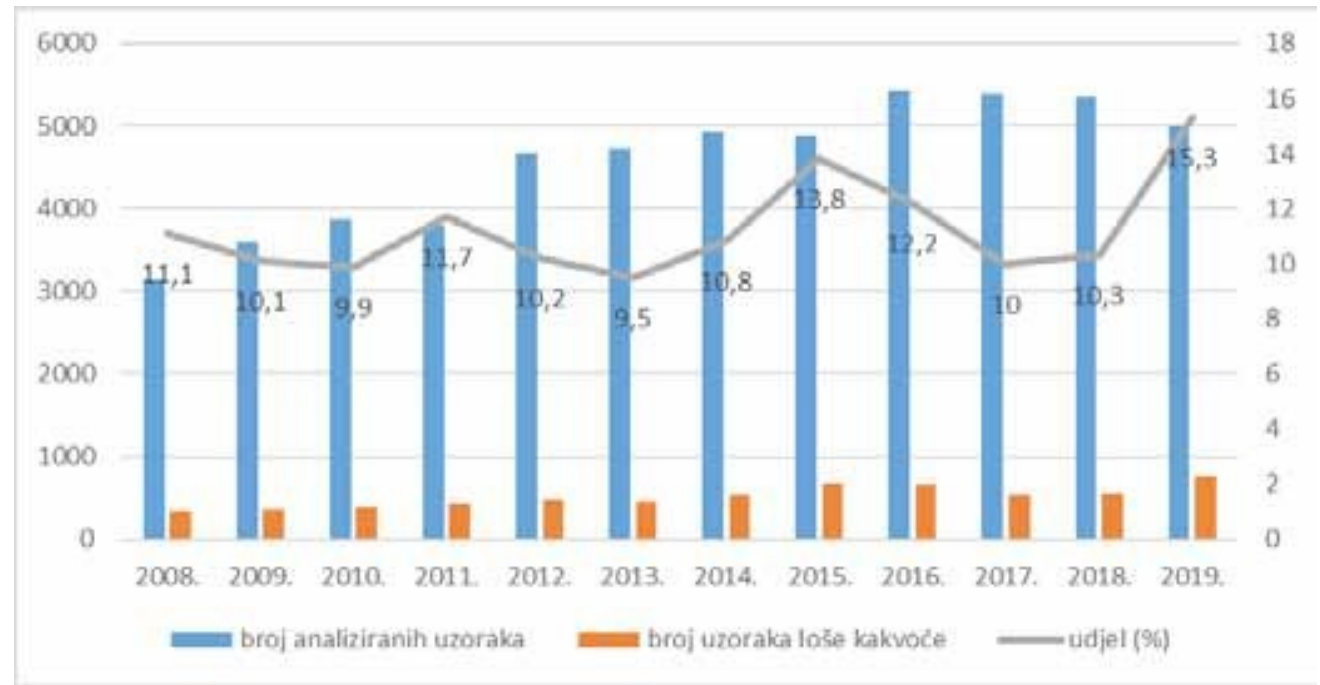

Grafikon 1. Senzorna ispitivanja u periodu 2008.-2019.

Graph 1. Sensory analyses, period 2008-2019

Neovisno o razlozima loše kakvoće, vidljivo je da nije moguće govoriti o kontinuiranom padu udjela loših uzoraka, što bi bilo poželjno i što bi upućivalo na podizanje razine kakvoće u ovom segmentu kontrole kakvoće; koeficijent determinacije koji govori o trendu u ovom razdoblju je $R^{2}=0,21$. Međutim, kada uzmemo u obzir čimbenike o kojima ovise ovi podaci, uključivo kontinuiran priliv novih subjekata na tržištu, često i bez stručne podrške u proizvodnji, onda su ovi podaci lakše razumljivi. Nadalje, senzorna ispitivanja provode se za uzorke koji predstavljaju vina spremna za tržište, međutim, određen broj uzoraka su vina u proizvodnji, što sigurno ima utjecaj na senzornu kakvoću i rezultate. $U$ analiziranom razdoblju izdvojili smo dvije godine $s$ većim udjelom uzoraka s manama i bolestima $u$ odnosu na ostale godine. $U$ 2019. zabilježen je najveći udio loših uzoraka, čak 15,3\%, druga godina s najlošijim rezultatima bila je 2015., s 13,8\%, dok su ostale godine u rasponu između 9,5 i 12\%.. Uz varijable koje nije moguće uzeti u obzir, poput enoloških tehnoloških postupaka, osobito onih koji su prethodili uzorkovanju, ipak možemo rezultate raspraviti u odnosu na ekološke uvjete proizvodnje grožđa. Berbe koje su prethodile navedenim godinama vezane su uz ekstremno zahtjevne klimatske godine; 2014. i 2018-toj. Obe godine obilježene su ekstremno toplim uvjetima uz kišne ekstreme, osobito u razdoblju važnom za dozrijevanje grožđa (https://meteo.hr/klima). Uz sve tehnološke čimbenike nakon berbe koji imaju kreativnu i kontrolnu snagu, ipak je ulazna kakvoća grožđa glavna odrednica potencijala kakvoće vina. Istovremeno, ekološke čimbenike kakvoće grožđa nije moguće ili je vrlo teško kontrolirati. Klimatske promjene, poglavito kroz 
sve češće ekstremne godine, uzrokuju kontinuiran stres koji se manifestira u promjenama fenofaza vinove loze, dozrijevanja i sastava grožđa, osobito aromatskog (van Leeuwen i DestracIrvine, 2017). Prema van Leeuwen i sur. (2004), klima je najvažniji čimbenik za procese koji se događaju u bobici tijekom dozrijevanja, te posljedično i uravnoteženog kvalitativnog sastava bobice koji značajno utječe na sastav budućeg vina.

Obzirom na prihvaćene norme EU, temeljnom razdiobom je moguće hrvatska vina podijeliti na vina bez zaštićene oznake izvornosti (ZOI) i vina sa ZOI. U grafikonu 2. prikazani su udjeli uzoraka sa ZOI i uzoraka bez ZOI u odnosu na ukupan broj analiza uzoraka vina, te udjeli loših uzoraka u navedenim grupama uzoraka.

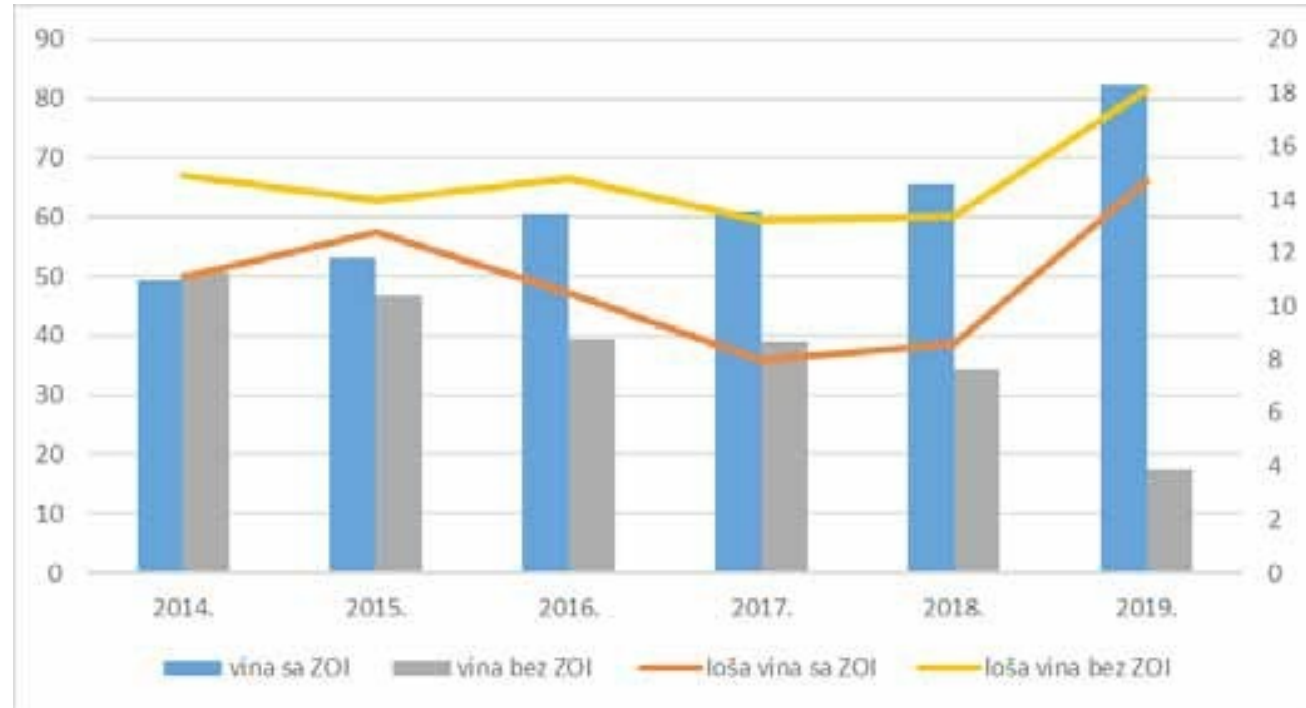

Grafikon 2. Udjeli uzoraka loše kakvoće u odnosu na pripadnost ZOI/bez ZOI (\%), razdoblje 2014.-2019.

Graph 2. Samples with faults in relation to PDO/non PDO (\%), period 2014-2019

lako je promatrano razdoblje relativno kratko, vidljiv je linearan trend povećanja broja uzoraka sa ZOI; koeficijent determinacije je $\mathrm{R}^{2}=0,87$. Zabilježen je i odgovarajući trend pada udjela uzoraka bez ZOI; koeficijent determinacije $R^{2}$ za razdoblje 2014.-2018. je 0,95. U određivanju trendova za ovu varijablu i varijable „loša vina“ nismo uzimali u obzir podatke za 2019. jer je $u$ toj godini prestala senzorna kontrola vina bez ZOI što je značajno promijenilo apsolutne vrijednosti te bi dalo iskrivljenu sliku trendova (grafikon 2.). Za udjel loših uzoraka sa ZOI bilježimo pad i pozitivan trend, iako niskog koeficijenta determinacije $\left(R^{2}=0,64\right)$. Nažalost, $u$ istom razdoblju pad udjela loših uzoraka vina bez ZOI još je manji, s koeficijentom determinacije 0,59. Taj podatak govori i o čimbenicima koji utječu na kakvoću ovih vina, prvenstveno standardima proizvodnje; razini tehnoloških znanja i mogućnosti, te interesima unutar populacije koja ova vina stavlja na tržište. Kada tome dodamo i činjenicu da kontrola kakvoće ovih vina više ne uključuje senzornu analizu prije stavljanja na tržište, nameće se pitanje u kojem će smjeru ići trend kakvoće ovih vina.

Obrada podataka o najvažnijim manama i bolestima kao razlozima loše senzorne kakvoće provedena je za razdoblje, od 2008. do 2019. (grafikon 3.), a dodatna analiza podataka o reduk- 
tivnim mirisima sumporovodika imerkaptana za razdoblje 2013.-2019 (grafikon4.).

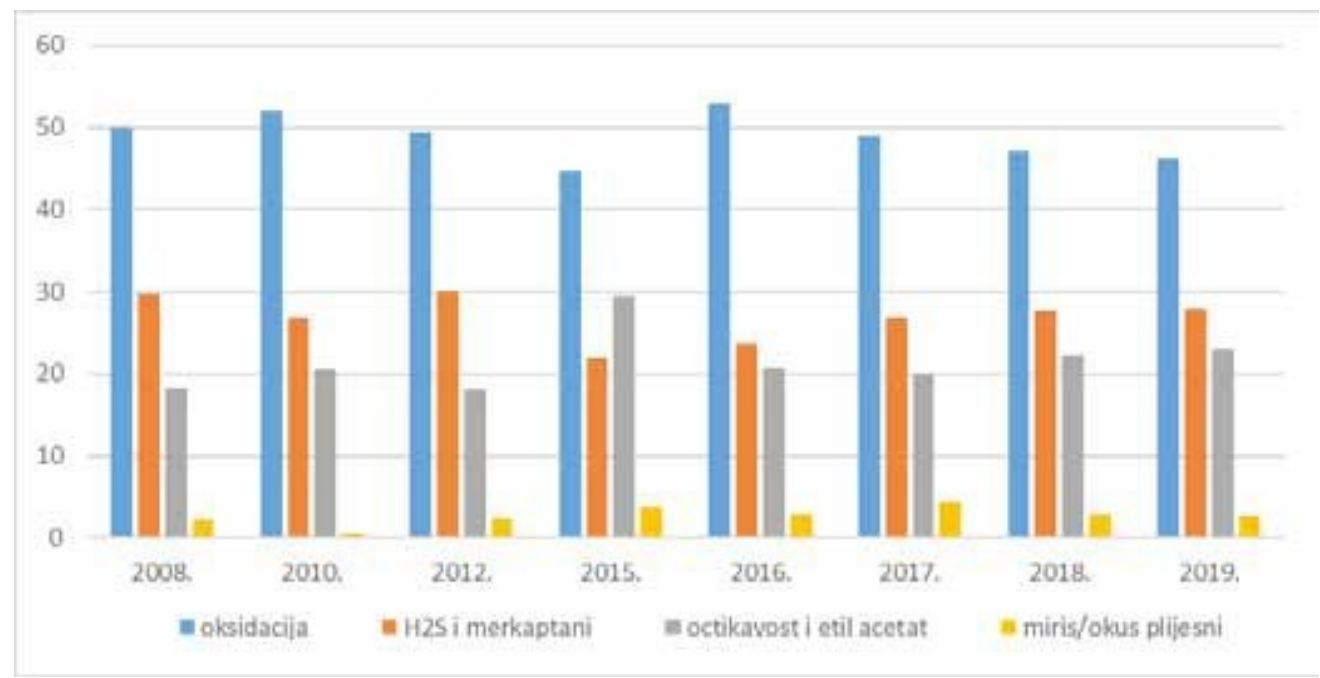

Grafikon 3. Najvažniji razlozi loše senzorne kakvoće, razdoblje 2008.-2019. (\%)

Graph 3. The most important wine faults, period 2008-2019

U odnosu na analizu rezultata senzornih ispitivanja za 2008. godinu, kao prvu godinu koju smo uzeli u obradu podataka (grafikon 1.), nema promjena intenziteta uzroka loše kakvoće. Oksidacija je i dalje najčešća mana, slijede ju reduktivni mirisi sumporovodika i merkaptana, octikavost i etil acetat, te plijesan kao vodeći između minornih razloga loše kakvoće. Niti za jedan od analiziranih razloga loše kakvoće nije zabilježen trend u promatranom razdoblju, ni u kojem smjeru. Međutim, ipak je moguće izdvojiti smanjenje pojave oksidacije, najvjerojatnije usljed promjene navika samih proizvođača, te uvođenja novih tehnologija, kao što su kontrolirani uvjeti tijekom proizvodnje, s naglaskom na hlađenje.

$\mathrm{U}$ analizu podataka smo uključili i problem plijesni jer je, iako minoran u smislu učestalosti, ipak važan s gledišta tehnologije i podrumskih uvjeta. Kao i za druge manje izražene probleme, tako i za plijesan nema pokazatelja trenda u bilo kojem smjeru.

Obzirom na kontinuiran problem reduktivnih mirisa na svjetskoj vinskoj sceni, za sumporovodik i merkaptanske mirise provedena je detaljna analiza podataka. Sumporovodik se pojavljuje kao samostalna mana, jednako kao i merkaptanski mirisi, ali je česta i kombinacija obe grupe mirisa (Fracassetti i Vigentini, 2017). Analiza zbirnih podataka odnosa udjela svih sumpornih reduktivnih spojeva i ostalih najvažnijih uzroka loše kakvoće, na razini čitavog promatranog razdoblja 2008.-2019. nije pokazala nikakav trend promjene (grafikon 3.). Problem reduktivnih mirisa, s naglaskom na sumporovodik je prvenstveno problem vezan uz raniji stadij proizvodnje, za razliku od oksidacije koja se može razviti jednako u svakom dijelu razvoja, od ranog stadija do bilo kojeg trenutka dozrijevanja. Priroda problema sumporovodika vidljiva je i kroz distribuciju uzoraka; najveći udjel takvih vina je u prvom kvartalu analize, u odnosu na berbu..

Međutim, zabrinjavajući su pokazatelji koje smo dobili analizom podataka posljednjih pet godina u odnosu na reduktivne mirise. $U$ tom razdoblju vidljiv je trend povećanja broja uzoraka s nepoželjnim sumpornim mirisima (grafikon 4.). Za odnos reduktivni mirisi/svi loši uzorci (oksidacija, reduktivni mirisi, octikavost i etil acetat) nema pokazatelja ikakvog trenda. 


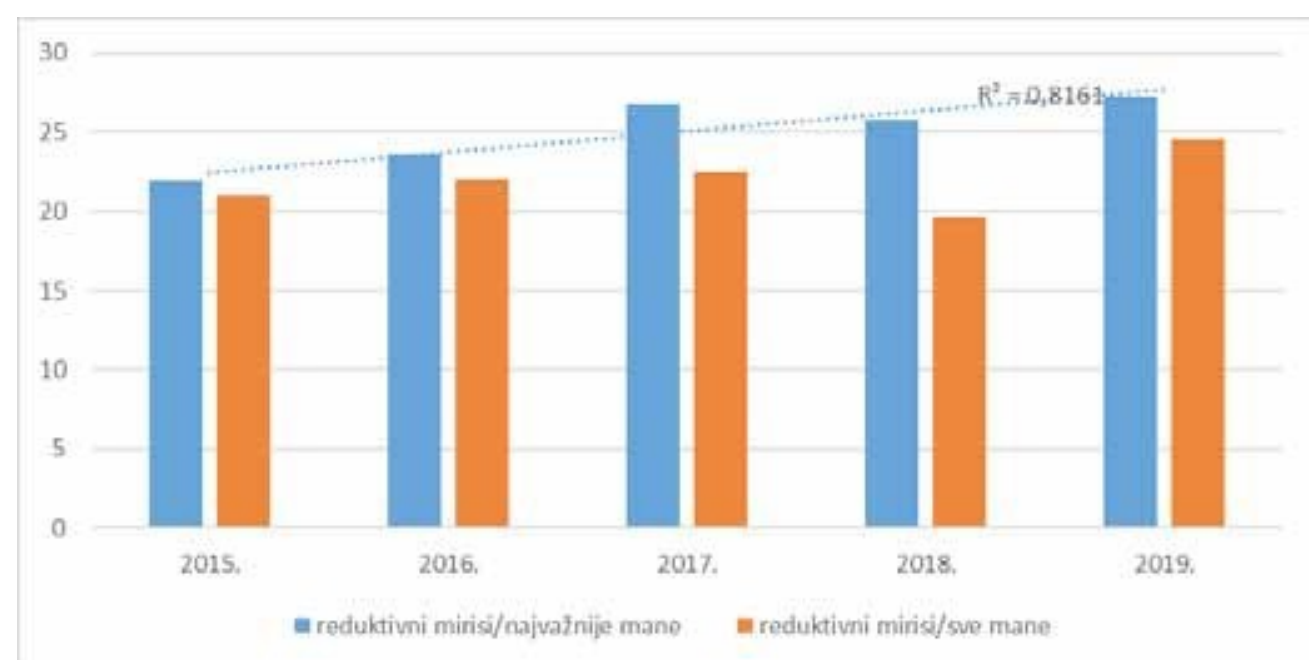

Grafikon 4. Mana reduktivnih mirisa u odnosu na najčešće 4 mane/ mana reduktivnih mirisa u odnosu na sve mane (\%), razdoblje 2015.-2019.

Graph 4. Reductive smell fault in relation to the most common 4 faults/ Reductive smell fault in relation to all faults (\%), period 2015-2019

Analizirane su varijable „uzorci s reduktivnim mirisima/uzorci s najčešće 4 mane“ u odnosu na,,uzorci s reduktivnim mirisima/svi loši uzorci“ (\%) te je za odnos uzorci s reduktivnim mirisima/uzorci s vodeće 4 mane izražen trend povećanja problema reduktivnih mirisa, koeficijent determinacije je $R^{2}=0,82$. Važno je pri tom naglasiti kako u 2019. nemamo podataka o senzornoj kakvoći vina bez ZOI jer je prekinut kontinuitet senzornih analiza za ova vina.

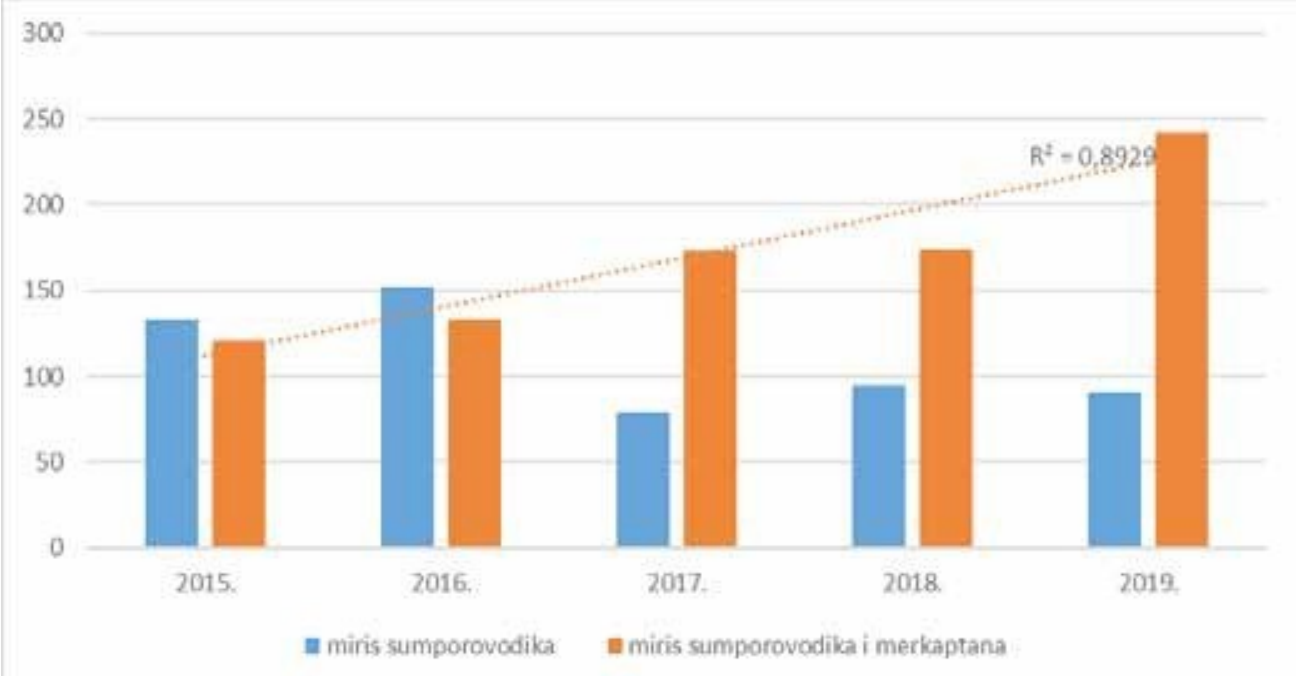

Grafikon 5. Raščlamba negativnih sumpornih mirisa, razdoblje 2015.-2019.

Graph 5. Analyse of negative sulphur odours, period 2015-2019 
Reduktivni mirisi podrazumijevaju sumporovodik, merkaptanske mirise i/ili njihovu kombinaciju. Kako su merkaptanski mirisi neusporedivo složeniji problem zbog mogućnosti naknadne pojave u podrumu i u boci, i nemogućnosti uklanjanja, proveli smo raščlambu deskriptora za posljednjih pet godina. Dobiveni rezultati vrlo su važni; sve je manja zastupljenost čistog mirisa sumporovodika, nasuprot čemu se bilježi porast pojave merkaptanskih mirisa uz sumporovodik (koeficijent determinacije je $\mathrm{R}^{2}=0,89$ ), kao i merkaptanskih mirisa bez sumporovodika (grafikon 5.). Kako je sumporovodik najčešća mana vina u ranom razvoju, analizirali smo distribuciju uzoraka u odnosu na vrijeme analize. $U$ proteklih pet godina zabilježen je trend porasta analiza u prvom kvartalu godine; od 25,8\% 2015. godine do 36,5\% 2019. godine, što je možda moglo utjecati na konačne rezultate, uzimajući u obzir činjenicu da je predmet analize uzorak, a ne pretpakovina, kako je već komentirano. Međutim, pokazatelji povećanja problema merkaptana nisu ovime nikako dovedeni u pitanje, obzirom na prirodu njihove pojave i kemijsku reaktivnost, a time i potencijalnih problema u boci.

\section{Zaključak}

Nepoželjni mirisi kontinuiran su problem kakvoće vina. Oksidacija, reduktivni mirisi sumporovodika i merkaptana, octikavost i etil acetat su glavni problemi i nisu zabilježene promjene u redoslijedu važnosti u analiziranom razdoblju 2008.-2019, u vinima prije stavljanja na tržište. Problem negativnih sumpornih spojeva, sumporovodika i merkaptanskih spojeva, zbog njihove reaktivnosti i nemogućnosti uklanjanja zahtijeva posebnu pozornost. Tome u prilog govore rezultati raščlambe uzroka loše senzorne kakvoće prije stavljanja vina na tržište u posljednjih pet godina. Zabilježen je trend porasta udjela uzoraka s merkaptanskim mirisima u odnosu na sumporovodik. Radi što sigurnijih podataka i pokazatelja stvarnih problema daljnje istraživanje trebalo bi uključiti analize pretpakovina s tržišta.

\section{Literatura}

Bell, S., Bell, C.P. (2007) Future Sense: Defining Brands through Scent. The Journal of the Marketing Society. 38, URL: http://www.marketingsociety.org.uk/About/manifesto/growthdrivers/Documents/ML_Stephen_Bell.pdf (1.9. 2020.) Biankini, P. L. (1884). Mane i bolesti vina i kako se lieče. Zadar. Narodni list Zadar.

Cliff, M.A., Pickering, G.J. (2006) Determination of odour detection thresholds for acetic acid and ethyl acetate in ice wine. J. Wine Research. 17, 45-52.

Ferreira, M. M. (2011) Yeasts and wine off-flavours: A technological perspective. Annals of Microbiology 61(1):95102. DOI: $10.1007 / \mathrm{s} 13213-010-0098-0$

Fracassetti D., Vigentini, I. (2017) Occurrence and analysis of sulfur compounds in wine. In: Grapes and Wines - Advances in Production, Processing, Analysis and Valorization. IntechOpen, str. 226-238. DOI: 10.5772/intechopen.72823

Franco-Luesma, E., Ferreira, V. (2014) Quantitative analysis of free and bonded forms of volatile sulfur compounds in wine. Basic methodologies and evidences showing the existence of reversible cation-complexed forms. Journal of Chromatography A 1359: 8-15. DOI: 10.1016/j.chroma.2014.07.011.

Goode J., Harrop. S. (2008) Wine faults and their prevalence: data from the world's largest blind tasting. Sulphur compounds production and sensory impact on wine. Proceedings of les XXES entretiens scientifiques Lallemand. Horsens, Denmark. 7-9. https://www.lallemandwine.com/wp-content/uploads/2014/10/ESL-2008-Horsens-Sulphur-compounds-production-and-sensory-impact-on-wine-Lee-el-documento.pdf

Huddelson, J. (2011) Wine Faults: Causes, Effects, Cures. San Francisco, USA, ISBN 978-1-934259-63-4.

IARC (1999) Monograph on the Evaluation Carcinogenic Risks to Humans, 71. International Agency for Research on Cancer, France.

intrinsic wine attributes. Food Quality and Preference, 21 (7), 741-754.

Jackowetz, J.N., de Orduna, R. M. (2013) Survey of SO2 binding carbonyls in 237 red and white table wines. Food Control. 32 (2) 687-692. DOI: 10.1016/i.foodcont.2013.02.001

Jones, P. R., M. J. Kwiatkowski, G. K. Skouroumounis, L. Francis, K. A. Lattey, E. J. Waters, I. S. Pretorius, and P. B. Hoi. (2004) Exposure of red wine to oxygen postfermentation. Wine Industry J. 19:17-24

Kinzurik, M. I., Herbst-Johnstone, M., Gardner, R. C., Fedrizzi B. (2016) Hydrogen sulfide production during yeast fermentation causes the accumulation of ethanethiol, S-ethyl thioacetate and diethyl disulfide. Food Chemistry 209: 341-347. DOI: 101016/i.foodchem.2016.04.094

Mc Govern, P., Jalabadze, M., Batiuk, S., Callahan, M.P., Smith, K.E., Hall, G. R., Kvavadze, E., Maghradze, D., Rusishvili, N., Bouby, L., Failla, O., Cola, G., Mariani, L., Boaretto, E., Bacilieri, R., This, P, Nathan Wales, N, Lordkipanidze, D. (2017) Early Neolithic wine of Georgia in the South Caucasus. PNAS. 114 (48) E10309-E10318; https://doi.org/10.1073/ 
pnas.1714728114

Muller, N., Rauhut, D. (2018) Recent development on the origin and nature of reductive sulfurous off-odours in wine. Fermentation. 4 (3) DOI: 10.3390/fermentation4030062

Mueller, S., Posidarz, P., Francis, I.L, Lockshi L. (2010) Filling the gap: measuring sensory and marketing impacts on wine choice. Australian Wine Business. 562. 108-111.

Rankine, B.C. (1963) Nature, origin and prevention of hydrogen sulfide aroma in wines. J. Sci. Food Agric. 14:79-91

Rimkute, J, Moraes, Ferreira, C. (2015) 'The effects of scent on consumer behaviour' International Journal of Consumer Studies, vol 40, no. 1, pp. 24-34. DOI: 10.1111/ijcs.12206. T

Semchyshyn, H.M. (2014) Reactive Carbonyl Species In Vivo: Generation and Dual Biological Effects. The Scientific World Journal, DOI: 10.1155/2014/417842

Steel, C., Blackman, J., Schmidtke, L. (2013) Grapevine Bunch Rots: Impacts on Wine Composition, Quality, and Potential Procedures for the Removal of Wine Faults. Journal of Agricultural and Food Chemistry 61(22). 5189-5205. DOI: 10.1021 /if400641r

Thoukis, G., L. A. Stern. (1962) A review and some studies of the effect of sulfur on the formation of offodors in wine. Am. J. Enol. Vitic.13:133-140.

van Leeuwen, C., Destrac Irvine, A. (2017) Modified grape composition under climate change conditions requires adaptations in the vineyards. OENO One. 51, 2, 147-154. DOI: 10.20870/oeno-one.2017.51.2.1647

van Leeuwen, C., Friant, Ph., Chone, X., Trégoat, O., Koundouras, S., Dubourdieu D. (2004) Influence of climate, soil and cultivar on terroir. Am. J. Enol. Vitic., 55, 207-217

Villamor, R. R., Ross. C. F. (2013). Wine matrix compounds affect perception of wine aromas. Annual Review of Food Science and Technology, 01 Jan 2013, 4:1-20. DOI: 10.1146/annurev-food-030212-182707

Vlahos, J. (2007) Scent and Sensibility. The New York Times. 9. URL: https://www.nytimes.com/2007/09/09/realestate/keymagazine/909SCENT-txt.html

Zoecklein, B.W. (2012) Production Wine Analyses. 98-111. Van Nostrand. USA. ISBN 978-1-4615-8146-8

Prispjelo/Received: 20.11.2020.

Prihvaćeno/Accepted: 1.12.2020.

\section{Frequency of reductive and other undesirable odours in wine quality control}

\section{Abstract}

The aroma of wine is a complex and creative reference of quality and avery important factor in the consumer choice of wine. The undesirable smell is therefore not acceptable, especially as some can be harmful to health. In addition to the continuity of the most important faults, an increase in the occurrence of complex unpleasant sulfur odors was observed in the last two decades. The goal of this study was to analyze the intensity of the occurrence of the most important wine faults in Croatian wines, before placing them on the market. Oxidation, volatile acidity, ethyl acetate, hydrogen sulfide, and mercaptans odours were studied. The results of sensory analyses of wine for the period 2008-2019 were processed. Additional analysis was performed for sulfur off-flavours for the period 2014-2019. Indicators of the decline in the share of samples with faults concerning all samples, were not obtained. The order of poor quality causes throughout the observed period was not changed, and it is as follows: oxidation, hydrogen sulfide and mercaptans, volatile acidity and ethyl acetate, and from minor problems mold. The increase in the problem of reductive smell, in general, has been observed. A serious problem is an increase in the fault of the mercaptans smell in the last five years. Although the technological standards of grape and wine production have advanced greatly, the causes of poor quality still exist, and some are even more pronounced.

Given the number and complexity of quality factors, these results suggest the need for constant monitoring of production and search for ways to prevent the emergence of undesirable wine odors.

Keywords: wine smell faults, hydrogen sulfite, mercaptans, sensory testingt 